DOI: 10.17117/na.2016.03.03.441

http://ucom.ru/doc/na.2016.03.03.441.pdf

Поступила (Received): 02.03.2016

\title{
Торгашкова О.Н.
}

\section{Токсическая активность воды реки Волги в окрестностях города Саратова}

\author{
Torgashova O.N. \\ The toxic activity of the water of the Volga \\ river near the city of Saratov
}

Проведены исследования по оценке состояния методом фитотестирования. Определена реакция тест-организма (пшеницы озимой) на уровень загрязнения воды некоторых участков реки Волги в окрестностях города Саратова. На основе морфофизиологической оценки проростков проведена оценка экологического состояния водных экосистем

Ключевые слова: биотестирование, фитотоксичность, антропогенная нагрузка, экологическая ситуация

\section{Торгашкова Ольга Николаевна}

Кандидат биологических наук, доцент

Саратовский государственный национально-

исследовательский университет им. Н.Г.

Чернышевского

2. Саратов, ул. Астраханская, 83
Conducted research assessment method phytoestrogen. Determined the response of the test organism (winter wheat) on the level of water pollution in some areas of the Volga river near the city of Saratov. On the basis of morphological and physiological evaluation of seedlings evaluated the ecological state of aquatic ecosystems

Key words: bioassay, the phytotoxicity of these anthropogenic environmental situation

\section{Torgashova Olga Nikolaevna}

Candidate of Biological Sciences, Associate Professor Saratov state national research university named N.G. Chernyshevsky

Saratov, Astrakhanskaya st., 83

В последнее время экологическое состояние рек характеризуется в значительном числе случаев как «прогрессирующая деградация». Это обусловлено в значительной мере антропогенным влиянием, вызывающим нарушения функционирования экосистем. Наиболее информативными для контроля за окружающей средой, становятся методы, являющиеся универсальными для разных регионов и загрязнений. По мнению исследователей, изучения загрязнения водной среды с помощью растительных тест-объектов является перспективным, так как позволяет выявить загрязнения водных экосистем на ранних стадиях и на локальном уровне, что дает возможность оперативно определять мероприятия по их устранению [1, с.74, 2, с.293, 3, с. 116].

Исследования проводились в районе острова Дубовая грива в Саратовском районе (пункт 1), в районе острова Казачий (пункт 2) и в прибрежной зоне поселка Увек (пункт 3). Оценка качества водных объектов проводилась на основе 
гидрохимических и биоиндикационных наблюдений по общепринятым методикам. Определение фитотоксичности проводили по методике проведения морфофизиологической оценки проростков озимой пшеницы» [4, с.160].

При оценке качества водной среды осуществляются: органолептические, гидрохимические и биоиндикационные исследования. Цвет практически во всех пунктах незначителен и колеблется от светло-желтого в пункте 1 и зеленовато-коричневого в пункте 3. Прозрачность воды больше в пункте 1 и меньше в пункте 3. В пункте 1 отмечался травяной запах с незначительной интенсивностью в 2 балла, на пункте 2 - болотный с интенсивностью 3 балла, на пункте 3 гнилостный, нефтяной с интенсивностью 4 балла. Интенсивность запаха в пункте 2 и 3 превышает предельно-допустимые показатели (выше 2 баллов).

Активная реакция среды находится в пределах допустимых значений. На всех участках вода мягкая; лишь в районе острова Дубовая грива, жесткость несущественно увеличивается и характеризуется как средняя. Содержание хлоридов, сульфатов, на всех участках не превышает предельно-допустимых значений. Концентрация нефтепродуктов, превышающая ПДК $(0,11$ мг/л), характерна для пункта 3.

При комплексной оценке степени загрязненности водной среды используется комбинаторный индекс загрязнения (КИЗ) и общая суммарная степень загрязнения (OCC3). КИЗ показал, что наблюдается снижение качества воды в пунктах 2 и 3 и она имеет 4 и 5 классы качества, что соответствует грязной и очень грязной воде, пункт 1 имеют 1 класс качества и вода характеризуются как условно чистая, по ОСС3 вода пункта 1, 2 относится к третьему классу качестваумеренно загрязненная, пункта 3 к четвертому классу качества - сильно загрязненная.

Для характеристики процессов, происходящих в водных объектах, определены коэффициенты донной аккумуляции (КДА), учитывающие способность загрязняющих веществ накапливаться в донных отложениях. Минимальные концентрации загрязняющих веществ зафиксированы в песчанистых донных отложениях выше Саратова (КДА = 2,50), а максимальные в песчанистых илах ниже Саратова (КДА $=5,70)$.

Исследованные нами пункты реки Волги находятся в двух функциональных зонах: рекреационной и селитебно-промышленной. По мере увеличения нагрузки оказываемой на реку, в направлении от рекреационной (остров Дубовая грива) к селитебно-промышленной зоне (от острова Казачий к поселку Увек), где значительно увеличивается количество источников загрязнения и их воздействие становится более агрессивным, что отражается на фитотоксичности воды в реке (рисунок 1).

В ходе исследования четко прослеживается тенденция увеличения количества непроросших семян при возрастании фитотоксичности. По числу непроросших семян селитебно-промышленная зона также превышает зону рекреации, если для нее в среднем минимум составляет 12 \%, то для зоны рекреации этот показатель 8 \%. О нарастании повышения загрязнения вод в селитебнопромышленной зоне можно судить по количеству семян с дефектами развития (в среднем их количество составляло 3-17 \%). 


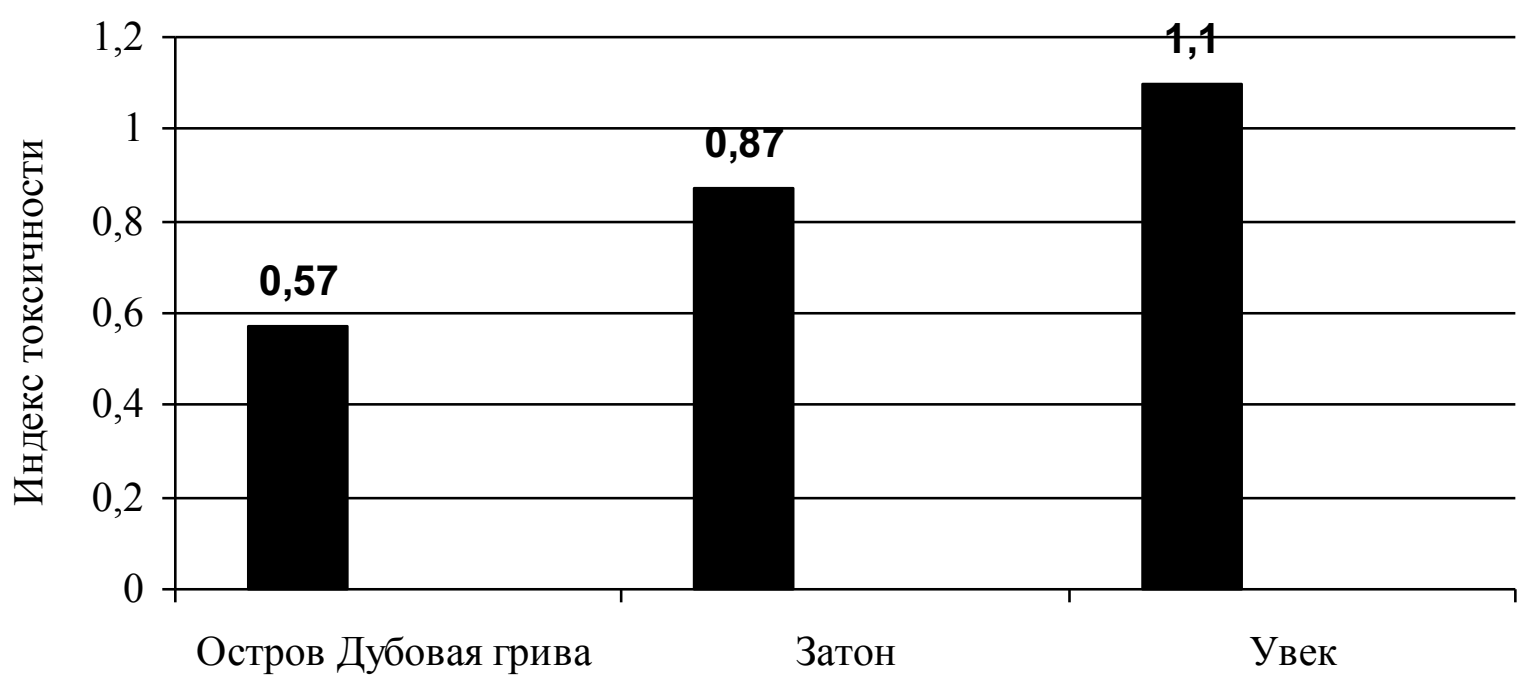

Рис. 1. Изменение фитотоксичности воды в исследованных пунктах

Сравнительна оценка морфофизиологических характеристик проростков озимой пшеницы в различных пунктах показала, что наибольшее угнетение роста корней и проростков характерно для селитебно-промышленной зоны. В пунктах 2.и 3 доминирующей является группа с тремя корнями. Вероятность развития озимой пшеницы с пятью зародышевыми корнями в рекреационной зоне больше, чем в селитебно-промышленной $(18,3$, и $1 \%$ соответственно). Анализ динамики соотношения групп проростков по длине стебля свидетельствует об изменении ее в различных функциональных зонах города, при этом увеличение длины стебля характерно для зоны реакреации. Для контрольного образца с отсутствием фитотоксического эффекта характерно доминирование проростков с длиной стебля более 10 см (84 шт.). В рекреационной зоне количество проростков с длиной стебля более 10 см сократилась более чем в 10 раз, а во всех пунктах промышленной зоны более чем в 20 раз.

Приведенный материал показывает, что вода изученных пунктов различается по фитотоксичности. Согласно методике критериев оценки экологической обстановки территорий для выявления зон чрезвычайной экологической ситуации и зон экологического бедствия, за комплексный показатель загрязнения принимают фитотоксичность [5, с.186]. По данной методике экосистему в районе Увека можно характеризовать как зону экологического бедствия, а в районе острова Казачий - как зону чрезвычайной экологической ситуации.

Таким образом, фитотоксичность вод реки нарастает по мере усиления антропогенной нагрузки на неё, что отражается в сравнительной оценке морфофизиологических характеристик проростков озимой пшеницы в различных пунктах реки Волги. 
2. Строганов Н.С., Филипенко О.Ф., Лебедева Г.Д. Основные принципы биотестирования сточных вод, оценка качества вод природных водоемов // Теоретические вопросы биотестирования. Волгоград, 1983. $293 \mathrm{c}$.

3. Торгашкова О.Н., Воловик Н.С., Опарина А.В., Левина Е.С. Оценка экологического состояния реки Волги в окрестностях Саратова // Изв. Сарат ун-та. Серия Химия. Биология. Экология. Саратов. 2014.

T.14. № 1. C. 113-116.

4. Федорова А.И., Никольская А.Н. Практикум по экологии окружающей среды. М.: Владос, 2001.

C. 160-163.

5. Касьяненко А.А. Современные методы оценки рисков в экологии. М.: Изд-во РУДН, 2008. 271 с.

(C) 2016, Торгашкова О.Н.

Токсическая активность воды реки Волги в окрестностях города Саратова (c) 2016, Torgashova O.N.

The toxic activity of the water of the Volga river near the city of Saratov 